\title{
Multimodal Resources to Facilitate Language Learning for Students with Special Needs
}

\author{
Kuang-yun Ting ${ }^{1}$ \\ ${ }^{1}$ Department of Applied English, St. John's University, Taiwan \\ Correspondence: Kuang-yun Ting, Department of Applied English, St. John's University, Taiwan. E-mail: \\ sandrine@mail.sju.edu.tw
}

Received: March 28, 2014 Accepted: May 6, 2014 Online Published: July 29, 2014

doi:10.5539/ies.v7n8p85 URL: http://dx.doi.org/10.5539/ies.v7n8p85

\begin{abstract}
Students with special needs are often isolated from the rest of the class and have to attend specific courses designed for them. This report describes an action-research project with two students with a hearing impediment and who were following a course at a university of science and technology. A student with mild autism was appointed as a teaching assistant because the course teacher wanted to provide him with the opportunity to express himself and to communicate with others. The course teacher presented material by means of an interactive whiteboard and video-based coursebook to maximise student understanding and foster learning, while the autistic assistant, also using an interactive whiteboard, often helped the two students go over what they had learned. A literature review focuses on the use of an interactive whiteboard and activity-theory in education, especially with students with special needs. This paper concludes with the statement that the findings were encouragingly positive. Suggestions are made to assist teachers who would like to take further steps towards the use of computer technology in special needs education.
\end{abstract}

Keywords: interactive whiteboard, activity theory, learning with special needs

\section{Introduction}

An interactive whiteboard is an instructional tool that uses a computer to project images onto a board. The projected image on the board can be manipulated. The important advantage of interactive whiteboards is to allow data entry simultaneously from many points, helping teachers plan curricula and facilitate understanding (Glover, Miller, Averis, \& Door, 2007). The major goal of education is to understand major ideas and themes (Gardner, 1993). Studies indicate that visuals can assist hearing-impaired students to improve their vocabulary acquisition and reading comprehension, and also enhance their understanding of what is taught in the classroom (Koskinen et al., 1993; Neuman \& Koskinen, 1992). In other words, the interactive whiteboard is expected to present visual forms to learners with special needs to develop a clear understanding of the topics. This project is a small-scale study, but it focuses on the vital role technology can play in promoting the education of students with special needs in class. The study provides recommendations for further study and implementation in the field of activity-theory, and for the use of interactive whiteboard in language teaching for students with special needs.

\section{Literature Review}

\subsection{The Application of Interactive Whiteboard}

Research shows that interactive whiteboards play an important role in creating a positive learning environment and in enhancing classroom teaching and learning (Bennett \& Lockyer, 2008; Betcher \& Lee, 2009; Hur \& Suh, 2012). It has been found that the application of the interactive whiteboard in the classroom substantially increases student motivation and participation in learning, especially at the beginning of its implementation (Harlow, et al., 2010; Hennessy, 2011; Higgins et al., 2007). Interactive whiteboard technology has recently become an indispensable tool in assisting teaching in a modern classroom throughout the world, or in collaborative projects (Cope \& Ward, 2002; Lee \& Gaffney, 2008). Teachers also agree that interactive whiteboards are as successful as traditional methods of teaching (Coyle, Yanez, \& Verdu, 2010; Schroeder et al., 2011). They create an opportunity for students to engage in the creation of spreadsheets and graphs (Wood \& Ashfield, 2008). Moreover, interactive whiteboards facilitate the presentation of visual forms to reinforce objectives (Maher et al., 2012; Türel \& Johnson, 2012). Learning material can be clearly displayed-a key factor 
for learners with hearing impairments.

However, certain difficulties in using interactive whiteboards in the classroom have been underlined by some studies (Gray et al., 2010; Vincent, 2007). Sometimes, teachers may encounter problems which delay the whole teaching process (Miller \& Glover, 2002). The students' initial interest might then be exhausted as the novelty gradually disappears (Beauchamp \& Parkinson, 2005). An interactive whiteboard is more expensive than a conventional whiteboard combined with a projector. If the surface of the interactive whiteboard is damaged, the replacement will be expensive. Further, some boards may jumble or distort information coming from several input devices at once. For these reason, an interactive whiteboard is not a popular facility in the classroom.

\subsection{Interactive Whiteboard and Its Impact on Students with Special Needs}

Hearing-impaired learners have difficulties in hearing and thus in learning by listening. For this reason, they mainly rely on visual learning. Technology such as the internet can compensate for their poor hearing in communication-activities. For example, they can communicate with others conveniently by using instant messenger software, email, Facebook, or other online applications. In addition, autistic students are helped by activities such as physical and verbal prompts to engage in learning. They can participate in several continuously changing and developing activities and still accomplish a specific task (Hall \& Higgins, 2005). An interactive whiteboard can provide rich multimodal resources and also serve as a meditational tool for creating an active setting for learners to develop language acquisition. Students with special needs can complete a task through touching, dragging and physically using their fingers and can enjoy using interactive whiteboards to explain, demonstrate and share what they have understood (Higgins, Beauchamp, \& Miller, 2007).

\subsection{Activity Theory}

Recent applications of language teaching approaches have emphasised student-centred instruction as an effective way of learning. This is because students are able to take charge of their own learning and they can actively participate in devising how to learn. In this case, activity-theory is an ideal tool to implement teaching plans in the language classroom. Research has shown that activities performed or preferred by students give them a feeling of responsibility for their work and the opportunity to participate more in the learning process (Engestrom, 2001). Such activities also liberate teachers from monitoring students and presenting relevant feedback (Shehadeh, 2004). Kearney and Schuck (2008) distinguish between intrinsic learning motivation and motivation linked to the technology. It is suggested that one of the primary features of interactive whiteboard technology is that it is able to attract students at the start (Shehadeh \& Coombe, 2012). Interactive whiteboards get students out of their seats and to the front of the class to actually manipulate elements on the board. Further, they can write on the whiteboard by using a finger, or search web pages, or complete a task at a pace suited to their individual needs. In other words, the touch-screen monitors are able to provide access to those students who learn best by touching, feeling and doing.

\section{Methodology}

This section introduces the scope of the project, the participants and two research inquiry strands.

\subsection{Scope of the Project}

The project took place in a University of Science and Technology class, during the academic year, September 2010--July 2011, i.e. over eight months. The main difficulty in learning a foreign language is the communication barrier between hearing-impaired students and their non-impaired peers. The special needs centre of the school provides hearing-impaired students with a specific class.

\subsection{Participants}

The participants were three students with special needs: two were hearing-impaired students attending a course called Basic English once a week for two hours over four months. The course mainly focused on vocabulary and short sentence learning. An assistant was normally arranged for the specific class to assist students with learning difficulties. In this case, the third student was an autistic assistant whose TOEIC score was 700, which meant that his English proficiency was at a higher level. He was appointed to be the assistant so as to boost his confidence. In the context of the research, the three research participants were given 'new names' to protect their privacy. 
Table 1. Students' background information

\begin{tabular}{lccc}
\hline Name & $\begin{array}{c}\text { Henry } \\
\text { (as the Assistant) }\end{array}$ & Natalie & Samuel \\
\hline Features & autism & mildly impaired hearing & quite severe hearing loss \\
English proficiency & intermediate TOEIC 700 & vocabulary and phrases & vocabulary \\
\hline
\end{tabular}

\subsection{Research Design}

In terms of the project's framework, an action research approach was taken towards a specific educational experience: using technology to teach learners with special needs by. This study was deliberately designed to enable participants to play an active role in the research process so as to allow the development and enhancement of teaching practice (Burns, 1999; Elliott, 1991; McNiff, 1993; Wallace, 1991). Accordingly, the study was conducted by individual teacher action research which normally limits the research to a specific classroom, issue. Teachers will decide whether a particular teaching methodology can improve their individual teaching practice or not after they themselves have recognised the classroom problems, in their choice of instructional strategies and learning materials (Sagor, 2000).

\section{Research Design}

A four-stage procedure is described below: the planning stage, the acting stage, the developing stage and the reflection stage.

\subsection{Step 1: The Planning Stage}

Action research is depicted as a cyclical process of change. The cycle begins with a series of planning actions. Thus, a lesson plan was designed to enhance teaching practice (Table 2).

Table 2. Lesson plan for an English lesson

\begin{tabular}{|c|c|c|c|}
\hline \multirow{2}{*}{\multicolumn{4}{|c|}{ Coursebook Title }} \\
\hline & & & \\
\hline Publisher & \multicolumn{3}{|c|}{$\begin{array}{l}\text { Heinle Cengage Learning, 1st edition, } 2006 \\
978-0838428115\end{array}$} \\
\hline Content & The coursebook & \multicolumn{2}{|c|}{$\begin{array}{l}\text { The coursebook provides a variety of subjects: schools, apartments, clothing, } \\
\text { weather, money, transport, job applications and visiting the doctor }\end{array}$} \\
\hline \multicolumn{2}{|c|}{ Language skills } & \multicolumn{2}{|c|}{ vocabulary, grammar, listening, speaking, reading, and a little writing } \\
\hline \multicolumn{2}{|c|}{ Teaching aids } & \multicolumn{2}{|c|}{$\begin{array}{l}\text { an interactive whiteboard, a laptop computer, a projector, a conventional } \\
\text { whiteboard }\end{array}$} \\
\hline \multicolumn{4}{|c|}{ Lesson possibilities } \\
\hline \multicolumn{4}{|c|}{ Class 1} \\
\hline Timing & \multirow{2}{*}{$\begin{array}{l}\text { Procedure } \\
\text { Present a unit: the teacher began } \\
\text { the lesson using a large screen. }\end{array}$} & Stage aim & Interaction patterns \\
\hline 20 minutes & & To introduce new language & Teacher to students \\
\hline 20 minutes & $\begin{array}{l}\text { Students wrote their answers on the } \\
\text { interactive whiteboard in turn. } \\
\text { Review the taught content: }\end{array}$ & To focus on accuracy & Individual work \\
\hline 10 minutes & $\begin{array}{l}\text { Students repeated the taught } \\
\text { vocabulary }\end{array}$ & To focus on speaking practice & Assistant to students \\
\hline \multicolumn{4}{|l|}{ Class 2} \\
\hline Timing & Procedure & Stage aim & Interaction patterns \\
\hline 20 minutes & $\begin{array}{l}\text { Review a unit: the assistant } \\
\text { reviewed the taught content, } \\
\text { underlining words in different } \\
\text { colours. }\end{array}$ & To give students fluency practice & $\begin{array}{l}\text { Assistant to students } \\
\text { Teacher monitors }\end{array}$ \\
\hline 20 minutes & $\begin{array}{l}\text { Game-like activities: vocabulary } \\
\text { bingo and scrabble }\end{array}$ & $\begin{array}{l}\text { For pleasure and to enhance } \\
\text { learning }\end{array}$ & Group activity \\
\hline 10 minutes & $\begin{array}{l}\text { The two students took a vocabulary } \\
\text { test. }\end{array}$ & To recall vocabulary & Individual work \\
\hline
\end{tabular}




\subsection{Step 2: The Acting Stage}

A lesson progressed in stages, based on learner interest or language proficiency. A typical lesson is explained below.

Stage 1: Introduction of the unit

The teacher introduced the unit - Hotel occupations - to the students on a large screen (Figure 1). The students were asked to look at and talk about the occupations. For example: Which hotel do you want to stay in when on vacation?

\section{Dictionary: Hotel Occupations}

\section{A. Listen and repeat.}

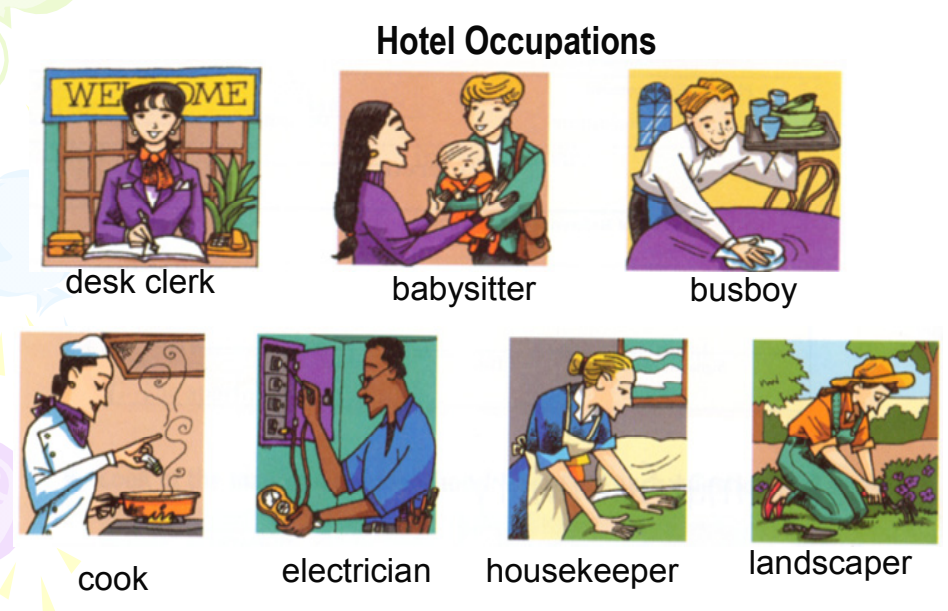

Figure 1. A sample unit of English in Action 1

Stage 2. Exercise practice

Students approached the whiteboard and added their answer by writing directly onto the whiteboard. After students completed the exercise on the interactive whiteboard, they were asked to write their answers to the questions in their book.

\section{Active Grammar: Present Tense}

\section{A. Match.}

\section{g 1. An airport shuttle driver}

2. A desk clerk

a. cleans and clears tables

3. A babysitter

b. washes and dries sheets and towels

4. A waitress

c. serves food

5. A cook

d. takes reservations

6. A laundry worker

e. repairs bathrooms

7. A housekeeper

f. is the supervisor

8. A manager

g. drives a van

9. A plumber

h. takes care of children

10.A busboy

i. prepares food

j. cleans and vacuums rooms

Figure 2. A sample exercise 
Stage 3. Game activities

After reviewing the vocabulary and phrases, a bingo game or scrabble was used in class. Learners as well as the assistant liked the word games very much. To play the word game, scrabble, for example, two learners and the assistant took turns to write words on the interactive whiteboards in an 8-by-8 grid (see Table 3).

Table 3. Scrabble game

\begin{tabular}{llllllll}
\hline $\mathrm{s}$ & $\mathrm{b}$ & $\mathrm{a}$ & $\mathrm{n}$ & $\mathrm{a}$ & $\mathrm{n}$ & $\mathrm{a}$ & $\mathrm{s}$ \\
$\mathrm{o}$ & $\mathrm{a}$ & & $\mathrm{b}$ & $\mathrm{a}$ & $\mathrm{g}$ & $\mathrm{e}$ & $\mathrm{l}$ \\
$\mathrm{u}$ & $\mathrm{c}$ & $\mathrm{s}$ & $\mathrm{e}$ & & $\mathrm{c}$ & & \\
$\mathrm{p}$ & $\mathrm{o}$ & $\mathrm{t}$ & $\mathrm{a}$ & $\mathrm{t}$ & $\mathrm{o}$ & $\mathrm{e}$ & $\mathrm{s}$ \\
$\mathrm{i}$ & $\mathrm{n}$ & $\mathrm{e}$ & $\mathrm{n}$ & & $\mathrm{r}$ & $\mathrm{g}$ & $\mathrm{t}$ \\
$\mathrm{z}$ & & $\mathrm{a}$ & $\mathrm{s}$ & & $\mathrm{n}$ & $\mathrm{g}$ & $\mathrm{e}$ \\
$\mathrm{z}$ & & $\mathrm{k}$ & & $\mathrm{t}$ & $\mathrm{u}$ & $\mathrm{n}$ & $\mathrm{a}$ \\
$\mathrm{a}$ & $\mathrm{p}$ & $\mathrm{p}$ & $\mathrm{l}$ & $\mathrm{e}$ & $\mathrm{s}$ & & $\mathrm{k}$ \\
\hline
\end{tabular}

The words were written across and down in crossword fashion and the teacher added as a single letter randomly to fill the blanks (see Table 4).

Table 4. Fill the blanks

\begin{tabular}{llllllll}
\hline $\mathrm{s}$ & $\mathrm{b}$ & $\mathrm{a}$ & $\mathrm{n}$ & $\mathrm{a}$ & $\mathrm{n}$ & $\mathrm{a}$ & $\mathrm{s}$ \\
$\mathrm{o}$ & $\mathrm{a}$ & $\mathrm{b}$ & $\mathrm{b}$ & $\mathrm{a}$ & $\mathrm{g}$ & $\mathrm{e}$ & $\mathrm{l}$ \\
$\mathrm{u}$ & $\mathrm{c}$ & $\mathrm{s}$ & $\mathrm{e}$ & $\mathrm{c}$ & $\mathrm{c}$ & $\mathrm{e}$ & $\mathrm{d}$ \\
$\mathrm{p}$ & $\mathrm{o}$ & $\mathrm{t}$ & $\mathrm{a}$ & $\mathrm{t}$ & $\mathrm{o}$ & $\mathrm{e}$ & $\mathrm{s}$ \\
$\mathrm{i}$ & $\mathrm{n}$ & $\mathrm{e}$ & $\mathrm{n}$ & $\mathrm{g}$ & $\mathrm{r}$ & $\mathrm{g}$ & $\mathrm{t}$ \\
$\mathrm{z}$ & $\mathrm{y}$ & $\mathrm{a}$ & $\mathrm{s}$ & $\mathrm{c}$ & $\mathrm{n}$ & $\mathrm{g}$ & $\mathrm{e}$ \\
$\mathrm{z}$ & $\mathrm{i}$ & $\mathrm{k}$ & $\mathrm{d}$ & $\mathrm{t}$ & $\mathrm{u}$ & $\mathrm{n}$ & $\mathrm{a}$ \\
$\mathrm{a}$ & $\mathrm{p}$ & $\mathrm{p}$ & $\mathrm{l}$ & $\mathrm{e}$ & $\mathrm{s}$ & $\mathrm{u}$ & $\mathrm{k}$ \\
\hline
\end{tabular}

When all the blanks were filled, learners played a crossword game in reverse (see Table 5). They each took turns to cross out a word and the person who found the last word was the winner.

Table 5. Crossword game

\begin{tabular}{llllllll}
\hline $\mathrm{s}$ & $\mathrm{b}$ & $\mathrm{a}$ & $\mathrm{n}$ & $\mathrm{a}$ & $\mathrm{n}$ & $\mathrm{a}$ & $\mathrm{s}$ \\
$\theta$ & $\mathrm{a}$ & $\mathrm{b}$ & $\mathrm{b}$ & $\mathrm{a}$ & $\mathrm{g}$ & $\mathrm{e}$ & $\mathrm{l}$ \\
$\mathrm{z}$ & $\mathrm{c}$ & $\mathrm{s}$ & $\mathrm{e}$ & $\mathrm{c}$ & $\mathrm{c}$ & $\mathrm{e}$ & $\mathrm{d}$ \\
$\mathrm{p}$ & $\boldsymbol{\theta}$ & $\mathrm{z}$ & $\mathrm{a}$ & $\mathrm{z}$ & $\theta$ & $\mathrm{e}$ & $\mathrm{s}$ \\
$\mathrm{i}$ & $\mathrm{n}$ & $\mathrm{e}$ & $\mathrm{n}$ & $\mathrm{g}$ & $\mathrm{r}$ & $\mathrm{g}$ & $\mathrm{t}$ \\
$\mathrm{z}$ & $\mathrm{y}$ & $\mathrm{a}$ & $\mathrm{s}$ & $\mathrm{c}$ & $\mathrm{n}$ & $\mathrm{g}$ & $\mathrm{e}$ \\
$\mathrm{z}$ & $\mathrm{i}$ & $\mathrm{k}$ & $\mathrm{d}$ & $\mathrm{t}$ & $\mathrm{u}$ & $\mathrm{n}$ & $\mathrm{a}$ \\
$\mathrm{a}$ & $\mathrm{p}$ & $\mathrm{p}$ & $\mathrm{l}$ & $\mathrm{e}$ & $\mathrm{s}$ & $\mathrm{u}$ & $\mathrm{k}$ \\
\hline
\end{tabular}

Stage 4. Review and Test

The teacher read out words to one of the two students while the assistant read the words to the other student, and 
the students then repeated the words after them. After reading the words, the two students did a quiz based on the vocabulary of the unit.

\subsection{Step 3: The Developing Stage}

This section discusses students' perceptions of the English course as well as the assistant's feedback. Three data collection techniques were used including observation, interviews and the participant journals.

Firstly, the teachers observed the participants' reaction to the educational process; for example, the interaction between the students and the assistant, their attitudes towards the course procedures and their feedback on class activities.

Secondly, interviews were used to collect data from the students and the assistant.

Data collected from observations can lead to valuable follow-up data collected through interviews (Fraenkel \& Wallen, 2003). The interviews were conducted in written form with pencil and paper. Moreover, the interview questions were divided into sections for the students to answer at the end of a lesson or an activity.

\subsection{Step 4: The Reflecting Stage}

The interactive whiteboard encouraged learners to become involved in the learning activities, because of the wide choice of tools to write the answer. They felt enthusiastic in choosing their favourite colours and printed the answer using digital pressure (Figure 3).

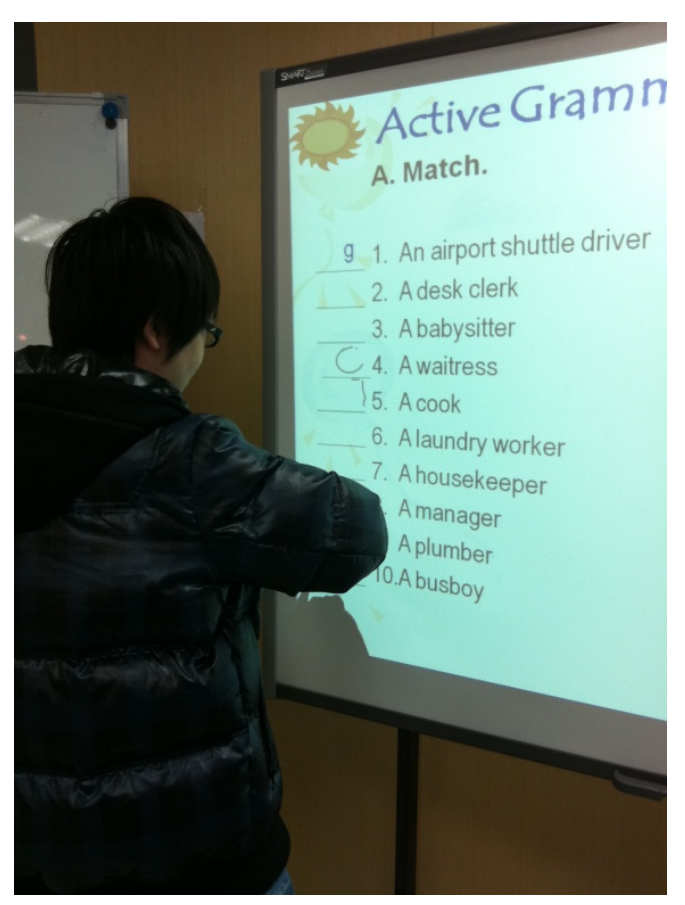

Figure 3. Student writing the answer with a figure

The scrabble activity retained the students' attention. The two hearing-impaired students were usually unable to remember any vocabulary, even if they had read it many times. In other words, vocabulary recognition would not have been possible before being exposed to the word game. Interestingly, although they had a hearing difficulty, they had excellent spatial intelligence. They could pick out words from a jumble of letters in the grids (Figure 4). 


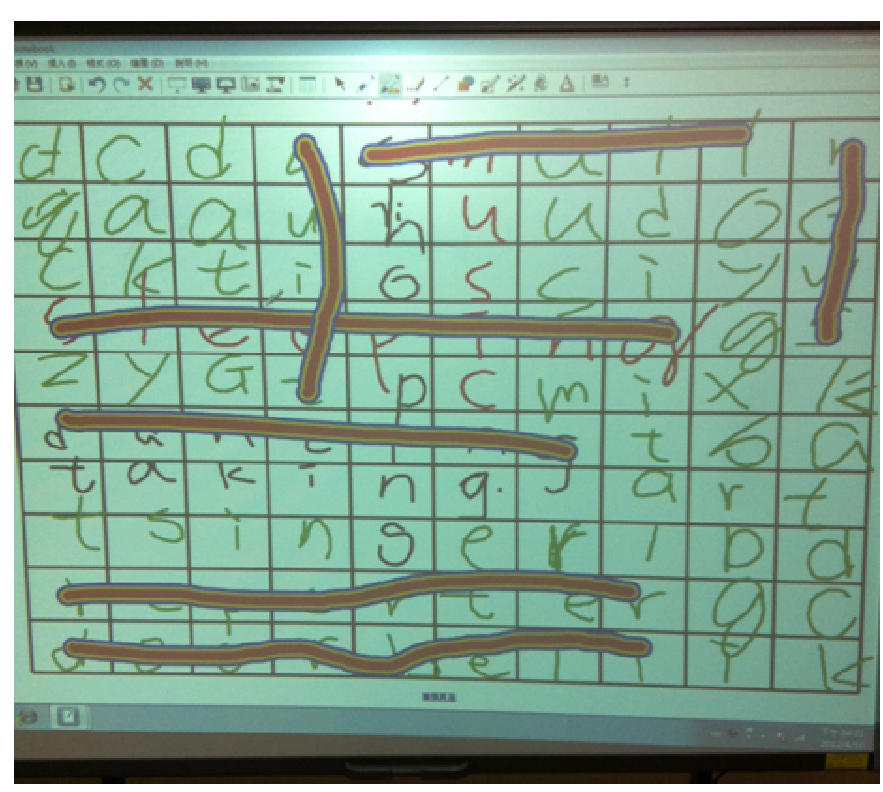

Figure 4. Students' participation of scrabble activity

When they looked for a word in the coursebook, they copied it onto the board with their fingers, they ended by learning it. They read the word at least three times. In this way, their engagement with the vocabulary was increased through the word game using the interactive whiteboard. By the end of the activity, both students had assimilated new words.

The interactive whiteboard had a great impact on Henry, the assistant, too. He liked being a tutor to junior students and also was able to criticise the use of the course book. He thought a video-based course book helped teachers maximise the potential of the course content.

The reason that I like the structure of the book is that we can repeat the video a lot of times until we finally understand what the characters are saying. The advantage of such a book is we can learn intonation patterns through watching the video at home, on the bus, or during the class. Also, when we don't know the words or the sentences, we can watch it again and again and we can read the subtitles if we want to match the subtitles with the dialogue in the video. What's more, we can repeat the intonation patterns in the video by imitating the sounds, the stress, and the sentences so as to learn the way people speak and express themselves in "real life". (World Link Intro)

In addition, Henry also mentioned the importance of a presentation tool to enhance understanding.

There is also a PowerPoint version of the book on a CD to let the students learn English by reading the contents of each file. By using the files, the teacher can control the tempo while teaching during the class or after the class and use them as supplementary material. (English in Action 1)

Henry's opinion confirmed the importance of visual material in learning languages especially for learners with special needs. He was actually very talkative, even though his autism did cause some difficulty, such as his wanting often to speak rather than listen thus making it difficult for the other learners. He was unable to understand personal space issues and was not aware of other people's feelings. He often exhorted the students to write the words quickly. He interacted only to reach a goal, not for the enjoyment of the activity.

Later, he was reminded by the teacher that his role as an assistant was primarily to give the two learners a chance to participate in the game. He came to appreciate the need for being a patient instructor so he slowed down, but he still enthusiastically participated in the game. His journal reflected his enthusiasm for the whiteboard. 
I have found that the whiteboard is so modern that it can assist teachers to teach a lot of subjects. If I become a teacher after graduation, I will use this method in my teaching because it is a useful and helpful tool that draws students'attention to their learning. (Henry)

What is also interesting is that the autistic student memorised all the spellings, but not the two hearing-impaired students. In future, teachingmaterial should be presented on the interactive whiteboard to maximise student understanding and create more opportunities for students to learn.

\section{Conclusion}

The aim of this project was to see if the use of interactive whiteboard technology could result in less confusion and limit distractions from the learning experience. It has explored the extent to which an interactive whiteboard can help students with special needs and the advantages and disadvantages of using it in such a context. The findings showed that by using visual-based instruction, teachers can create an environment in which students with impaired hearing as well as autistic students can become more involved and their learning ability improved. In other words, the interactive whiteboard is indeed opening up new avenues of communication for students with special needs, including students with autism and students with impaired hearing.

\section{References}

Beauchamp, G., \& Parkinson. (2005). Beyond the 'wow' Factor: Developing interactivity with the interactive whiteboard. School Science Review, 86, 97-103.

Bennett, S. J., \& Lockyer, L. (2008). A study of teachers' integration of interactive whiteboards into four Australian primary school classrooms. Learning, Media and Technology, 33(4), 289-300. http://dx.doi.org/10.1080/17439880802497008

Betcher, C., \& Lee, M. (2009). The interactive whiteboard revolution: Teaching with IWBs. Australia: ACER Press.

Burns, A. (1999). Collaborative Action Research for English Language Teachers. Cambridge: Cambridge University Press.

Cope, C., \& Ward. (2002). Integrating Learning Technology into Classrooms: The importance of teachers' perceptions. Education Technology and Society, 5(1), 1-11.

Coyle, Y., Yanez, L., \& Verdu, M. (2010). The impact of the interactive whiteboard on the teacher and children's language use in an ESL immersion classroom. System, 38(4), 614-625.

Elliott, J. (1991). Action Research for Educational Change. Buckingham: Open University Press.

Engestrom, Y. (2001) Expansive learning at work: Toward an activity theoretical reconceptualization. Journal of Education and Work, 14(1), 133-156.

Fraenkel, J. R., \& Wallen, N. E. (2003). How to design and evaluate research in education. Boston: McGraw-Hill Higher Education.

Gardner, H. (1993). Multiple intelligences: The theory in practice. New York: Basic Books.

Glover, D., Miller, D., Averis, D., \& Door, V. (2007). The evolution of an effective pedagogy for teachers using the interactive whiteboard in mathematics and modern languages: An empirical analysis from the secondary sector. Learning, Media, \& Technology, 32(1), 5-20.

Gray, C., Hagger-Vaughan, L., Pilkington, R., \& Tomkins, S. A. (2010). The pros and cons of interactive whiteboards in relation to the key stage 3 strategy and framework. Language Learning Journal, 32, 38-44. http://dx.doi.org/10.1080/09571730585200171

Hall, I., \& Higgins, S. (2005). Primary school students' perceptions of interactive whiteboards. Journal of Computer Assisted Learning, 21, 102-117. http://dx.doi.org/10.1111/j.1365-2729.2005.00118.x

Harlow, A., Cowie, B., \& Heazlewood, M. (2010). Keeping in touch with learning: The use of an interactive whiteboard in the junior school. Technology, Pedagogy and Education, 19(2), 237-243. http://dx.doi.org/10.1080/1475939X.2010.491234

Hennessy, S. (2011). The role of digital artefacts on the interactive whiteboard in supporting classroom dialogue. $\begin{array}{lllll}\text { Journal of } & \text { Computer } & \text { Assisted }\end{array}$ 
http://dx.doi.org/10.1111/j.1365-2729.2011.00416.x

Higgins, S., Beauchamp, G., \& Miller, D. (2007). Reviewing the Literature on Interactive Whiteboards. Learning, Media and Technology, 32(3), 213-225. http://dx.doi.org/10.1080/17439880701511040

Hur, J. W., \& Suh, S. (2012). Making learning active with interactive whiteboards, podcasts, and digital storytelling in ELL classrooms. Computers in the Schools, 29(4), 320-338. http://dx.doi.org/10.1080/07380569.2012.734275

Kearney, M. D., \& Schuck, S. R. (2008). Exploring pedagogy with interactive whiteboards in Australian schools. Australian Educational Computing, 23(1), 8-13.

Koskinen, P. S., Wilson, R. M., Gambrell, L. B., \& Neuman, S. B. (1993). Captioned video and vocabulary learning: An innovative practice in literacy instruction. The Reading Teacher, 47(1), 36-43.

Lee, M., \& Gaffney, M. (2008). Leading a Digital School: Principles and practice. Camberwell, Vic.: ACER Press.

Maher, D., Phelps, R., Urane, N., \& Lee, M. (2012). Primary school teachers' use of digital resources with interactive whiteboards: The Australian context. Australasian Journal of Educational Technology, 28(1), $138-158$.

McNiff, J. (1993). Teaching as Learning: An Action Research Approach. London: Routledge. http://dx.doi.org/10.4324/9780203187999

Miller, D., \& Glover, D. (2002). The interactive whiteboard as a force for pedagogic change: The experience of five elementary schools in an English education authority. Information Technology in Childhood Education Annual, (1), 5-19.

Neuman, S. B., \& Koskinen, P. S. (1992). Captioned television as comprehensible input: Effects of incidental word learning in context for language minority students. Reading Research Quarterly, 27, 95-106. http://dx.doi.org/10.2307/747835

Sagor, R. (2000). Guiding School Improvement with Action Research. Alexandria VA, Association for Supervision and Curriculum Development (ASCD).

Schroeder, M. M., Burns, C. S., \& Reicks, M. M. (2011). Interactive Whiteboards: A New Tool for Extension Education. Journal of Extension, 49(5), 25.

Shehadeh, A. (2004). Modified output during task-based pair interaction and group interaction. Journal of Applied Linguistics, 1(3), 351-382. http://dx.doi.org/10.1558/japl.2004.1.3.351

Shehadeh, A., \& Coombe, C. A. (2012). Task-Based Language Teaching in Foreign Language Contexts: Research and Implementation. Amsterdam: John Benjamins Publishing Company. http://dx.doi.org/10.1075/tblt.4

Türel, Y. K., \& Johnson, T. E. (2012). Teachers' Belief and Use of Interactive Whiteboards for Teaching and Learning. Journal of Educational Technology \& Society, 15(1), 381-394.

Vincent, J. (2007). The interactive whiteboard in an early years classroom: A case study in the impact of a new technology on pedagogy. Australian Educational Computing, 22(1), 20-25.

Wallace, M. (1991). Training Foreign Language Teachers: A reflective approach. Cambridge: Cambridge University Press.

Wood, R., \& Ashfield, J. (2008). The use of the interactive whiteboard for creative teaching and learning in literacy and mathematics: A case study. British Journal of Educational Technology, 39(1), 84-96.

\section{Copyrights}

Copyright for this article is retained by the author(s), with first publication rights granted to the journal.

This is an open-access article distributed under the terms and conditions of the Creative Commons Attribution license (http://creativecommons.org/licenses/by/3.0/). 